\title{
Platelet BACE1 levels as a possible biomarker for Alzheimer's disease
}

\author{
Boris Decourt, Aaron Walker, Amanda Gonzales, Michael Malek-Ahmadi, Carolyn Liesback, Kathryn Davis, \\ Christine Belden, Sandra Jacobson, Marwan Sabbagh \\ From Molecular Neurodegeneration: Basic biology and disease pathways \\ Cannes, France. 10-12 September 2013
}

\section{Background}

To date there is no validated peripheral biomarker to assist with the clinical diagnosis of Alzheimer's disease (AD). On the other hand, platelet proteins have been studied as AD biomarkers with relative success. In the present study we investigated whether platelet BACE1 levels differ between $\mathrm{AD}$ and cognitively normal $(\mathrm{CN})$ control patients.

\section{Materials and methods}

We collected blood samples from $12 \mathrm{CN}$ and $15 \mathrm{AD}$ subjects using a standardized procedure. All samples were processed within 5-60 min after collection. Blood fractions were separated by successive centrifugations: red blood cells, platelet-rich fraction, and platelet-poor plasma. Both platelet and plasma samples were analyzed using a newly developed BACE1 ELISA method and Western blotting.

\section{Results}

ELISA analysis showed that platelet BACE1 levels were significantly lower in AD compare to $\mathrm{CN}$ subjects (12\% decrease, $\mathrm{p}<0.05)$. These data were supported by Western blotting which indicated that several BACE1 isoforms $(37,45,56,70 \mathrm{kDa})$ were significantly less abundant in AD platelets. However, no significant difference between the two groups was noted in plasma fractions.

\section{Conclusions}

Our pilot study suggests that circulating platelets possess less $\mathrm{BACE} 1$ protein $\mathrm{AD}$ subjects. This provides evidence for testing platelet BACE1 levels as a peripheral AD biomarker using our novel, sensitive and inexpensive ELISA method. We are currently investigating this hypothesis

\footnotetext{
Banner Sun Health Research Institute, Sun City, AZ, United States Minor
} Outlying Islands

(C) 2013 Decourt et al; licensee BioMed Central Ltd. This is an Open Access article distributed under the terms of the Creative Commons Attribution License (http://creativecommons.org/licenses/by/2.0), which permits unrestricted use, distribution, and reproduction in any medium, provided the original work is properly cited. using larger groups as well as Parkinson's disease subjects to verify the specificity of the approach.

\section{Acknowledgments \\ This project was supported by National Institute on Aging grants R01AG034155, P30AG019610-09, and 5P30AG019610-12.}

Published: 13 September 2013

doi:10.1186/1750-1326-8-S1-P14

Cite this article as: Decourt et al:: Platelet BACE1 levels as a possible biomarker for Alzheimer's disease. Molecular Neurodegeneration 2013 8(Suppl 1):P14.
Submit your next manuscript to BioMed Central and take full advantage of:

- Convenient online submission

- Thorough peer review

- No space constraints or color figure charges

- Immediate publication on acceptance

- Inclusion in PubMed, CAS, Scopus and Google Scholar

- Research which is freely available for redistribution 